\title{
THE CASE FOR MARKET-BASED STRESS TESTS*
}

\author{
John Vickers \\ All Souls College, Oxford
}

June 2019

\begin{abstract}
The paper contends that, for major banks with price-to-book ratios less than one, stress tests based on market values should be run and published by regulators alongside existing stress test results.
\end{abstract}

Keywords: banks, capital requirements, price-to-book ratios, stress tests

JEL Codes: G21, G28

\section{INTRODUCTION}

Given that bankers, commentators and even regulators often speak about banks "holding" capital, it is perhaps natural to think in colloquial terms of bank capital as like a pot of money that banks keep on one side for a rainy day. But of course the pot-of-money metaphor is fallacious. A pot of money is an asset, but equity capital is on the liability side of the balance sheet - part of banks' funding structure. It is the difference between two big numbers - the estimated value of their assets and their liabilities (i.e. obligations to depositors, bond-holders, etc.).

The fallacy is dangerous not just because it confuses assets and funding. It also promotes a spurious sense of precision. You can count how much money is in a pot but you can't measure bank capital - in particular its ability to absorb loss - with much accuracy at all. Given the potentially huge economic and social costs of bank failure through capital inadequacy, this is a serious policy issue.

Indeed the measurement problem is inherent to what banks do. Among other things they provide liquidity transformation. Depositors, for example, can get liquidity on demand while their funds are invested in part in illiquid assets such as loans. In the nature of things, values of illiquid assets are hard to measure. There are accounting measures, upon which

\footnotetext{
* This paper is the edited version of a keynote address given at the 19th Annual International Conference on Policy Challenges for the Financial Sector, IMF, Washington DC, on 6 June 2019. Without implicating them in any way, I thank Anat Admati, Dean Buckner, Jeremy Bulow, John Cochrane, Kevin Dowd, Morris Goldstein, Martin Hellwig, Paul Klemperer, David Miles, Markus Parlasca, Natasha Sarin, Hyun Shin, Paul Tucker and Bank of England staff for helpful exchanges on the topic of this paper. It develops, and in places draws from, John Vickers, 'Safer, but not safe enough', keynote address at the 20th International Conference of Banking Supervisors, Abu Dhabi, 29 November 2018.
} 
the edifice of prudential regulation depends, and there are market measures. The two may come apart, however, as they did spectacularly in the crisis of a decade ago. ${ }^{1}$ For a number of major banks they are apart again now, and have been for a while. What, if anything, should regulators do about that? Not worry about it? Go over to market-based measures? But then what about the risk of nasty pro-cyclical dynamics?

Like many economists, I will argue that market-based measures should play a greater role in regulatory assessment than is current practice. ${ }^{2}$ Stress tests are an increasingly important element of that practice. In particular, I will contend that: for major banks with price-tobook ratios less than one, stress tests based on market values should be run and published by regulators alongside existing stress test results.

This could be done in at least two ways, which are discussed below. Simplest, and what I mainly have in mind, is what I'll call the ex ante method of using market values to calibrate the starting point for the test. Thus market values would be one basis for setting the initial capital levels that are then subject to stress. The ex post method, so to say, goes further and considers the projected erosion of market values during the stress, to test whether the degree of stress is market-consistent. ${ }^{3}$ Thus the ex ante method uses market-based capital measures to gauge the pre-shock situation, while the ex post method considers implications post-shock for market-based measures of capital.

When I proposed to the Bank of England in 2016 that parallel stress tests based on market values be run, they responded ${ }^{4}$ with a number of counter-arguments, which I will review below together with some remarks on illiquidity issues. I will also make some comments on Bank of England stress tests of banks and on an aspect of their current proposals for stress tests of insurance companies with defined benefit pension schemes. But first here are some facts about banks' price-to-book ratios.

\section{CAPITAL MEASUREMENT AND PRICE-TO-BOOK RATIOS}

The theme of the IMF's Global Financial Stability Report of October 2018 was: a decade after the financial crisis, are we safer? In many respects yes, but ...

"In the euro area, China, Japan, and the United Kingdom, bank aggregate price-to-book ratios are less than one. This means that the market value of equity is less than the

\footnotetext{
${ }^{1}$ See Andy Haldane 'Capital discipline', speech at the American Economic Association, 9 January 2011.

${ }^{2}$ For example, the great majority of respondents to the recent Bank of Finland survey on bank capital requirements supported the use of market-based measures to complement (or replace) book-/accountingbased capital requirements. On the use of market values in stress tests, see for example, Viral Acharya, Diane Pierret and Sascha Steffen, 'Capital shortfalls of European banks since the start of the banking union' (2016) NYU Stern School of Business; Jeremy Bulow, 'How stress tests fail', voxeu.org, 9 May 2019; and Morris Goldstein, Banking's Final Exam (Peterson Institute for International Economics 2017).

${ }^{3}$ This is the method of Natasha Sarin and Larry Summers, 'On market-based approaches to the valuation of capital', (2019) Handbook of Financial Stress Testing, forthcoming.

${ }^{4}$ See the letter from Mark Carney of 19 December 2016, available via bankofengland.co.uk.
} 
amount of capital booked on bank balance sheets. If market valuations are used to calculate capital ratios - in place of the balance sheet value of capital used in the regulatory ratios - a number of banks would have a market-adjusted capitalization of less than 3 per cent, the minimum level in the Basel III framework". ${ }^{5}$

The two charts below, from Figure 1.20 in that report, illustrate.

\section{... but equity market valuations are mixed.}

\section{Bank Price-to-Book Ratios}

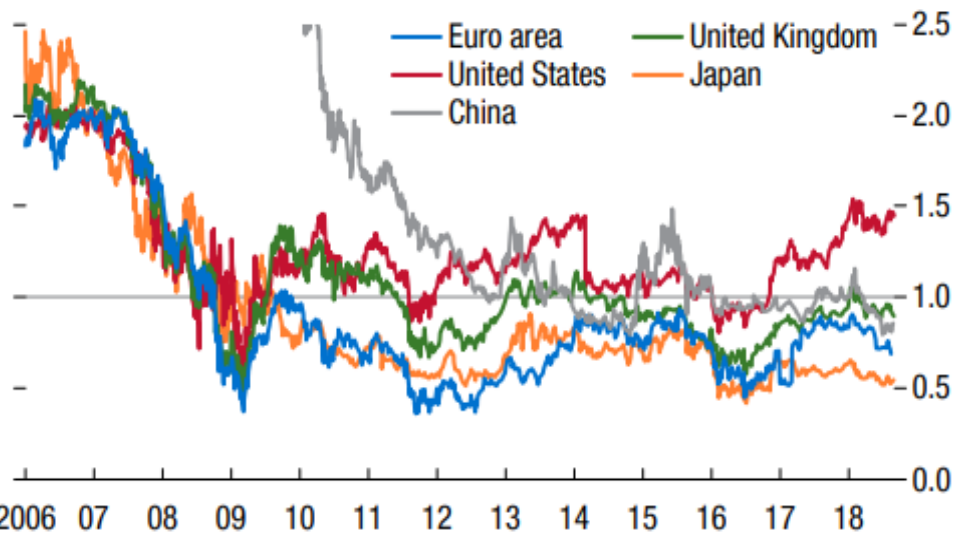

The first chart shows that average price-to-book ratios are below one in all the regions shown except the US. Pre-crisis they were about two, which shows how wrong markets can be, but markets reflected the problems emerging through 2007-8 much more quickly than the lagging regulatory numbers.

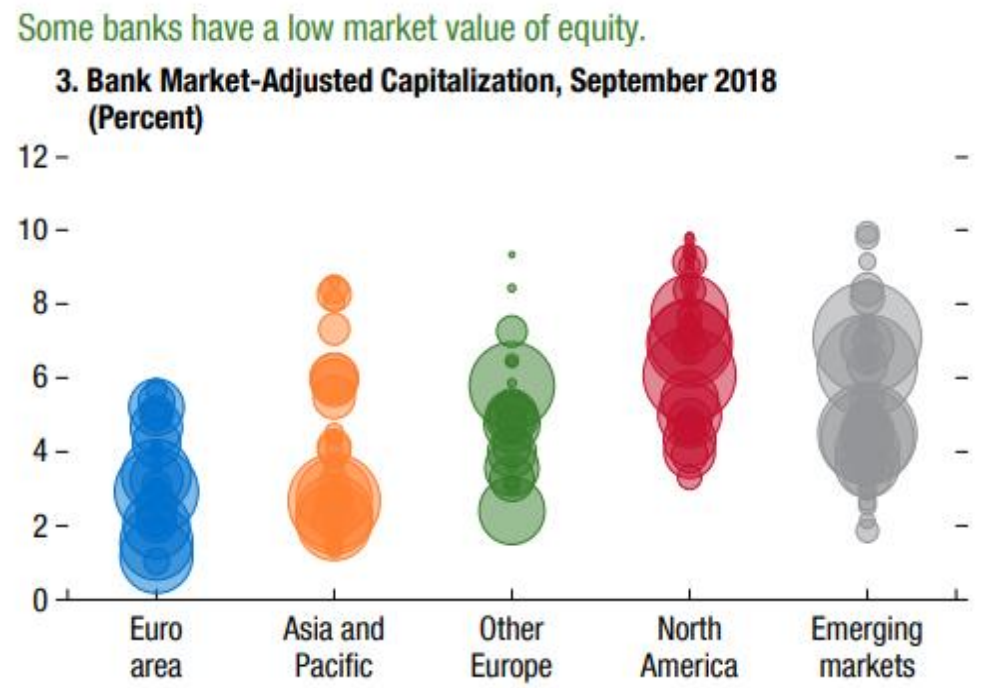

The next chart shows banks' market-adjusted capitalisation by region. That is the price-tobook ratio (if less than one) times tangible common equity as a proportion of adjusted tangible assets. Blob size is proportional to assets, so bigger banks have bigger blobs. On a 
market-adjusted view, some major banks have very high leverage despite a decade of reform.

Finally here is a more recent chart from Figure 1.5 of the IMF's April 2019 GFSR:

\section{Some banking systems need to continue strengthening their balance} sheets.

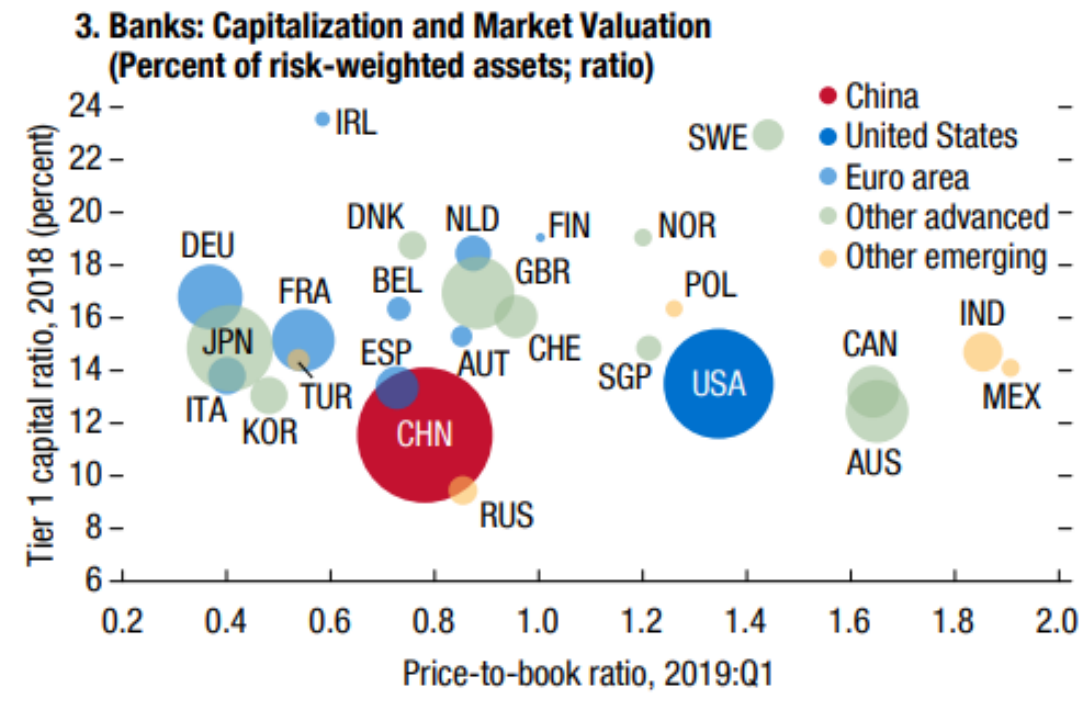

It is evident that bank's price-to-book ratios are well below one, and persistently so, in much of the world. The data in the first and last chart are by region or country, so some banks, including major ones, have ratios substantially lower than the average of which they are part.

If the market believed book values, price-to-book ratios should substantially exceed one. That is because market capitalisation reflects a view of

- the value of current assets less liabilities plus

- the franchise value of future profits in excess of the cost of capital, plus

- the option value arising from shareholders' limited liability and implicit subsidy. Book values reflect the first element. The future franchise value should be significantly positive, given that there is less-than-perfect competition in banking, if management is competent enough not to take on business that is expected to be value-reducing. ${ }^{6}$ And the option value, which cannot be negative, is positive if there is any possibility of bail-out.

\footnotetext{
${ }^{6}$ The assumption of managerial competence, in the sense used here, cannot be taken for granted. Departing from it could reconcile correct asset valuations with price-to-book values below one, but in a way that raises troubling questions, including for prudential regulation. Banks whose management is inclined to make valuereducing investments would appear in need of extra strong capital buffers.
} 
Regulatory measures of capital are based on book values, but with adjustments. Thus CET1 rightly excludes some elements of shareholder value that would not absorb loss in a crisis. Parallel adjustments would be required for capital measures based on market values.

Price-to-book ratios persistently below one therefore raise the question of whether regulatory measures are accurate - a question that should always be in mind anyway.

Stress tests are designed to assess how well the system would deal with a shock. They typically assume that we know where we are to begin with, before the shock. But what if we don't know for sure where we are? What if there are reasons to think that we might be in a more vulnerable state, pre-shock, than assumed in the standard type of test? Stress tests that ignore that possibility are running a serious risk, which should be of particular concern to prudential regulators. There is the further danger that, by ignoring or playing down the risk, stress tests might give such false comfort as to be counterproductive.

Saying this does not for a moment suppose that markets always assess value correctly. The market could well be taking an unduly pessimistic view, but there is a chance that it is not. We just don't know. The sensible response to uncertainty, to ignorance putting it bluntly, is to be pluralist. Neither assume that the market is right nor that accounting numbers are right. Look at things on both bases, and compare them.

Hence the suggestion that it would be good practice, for banks with price-to-book ratios below one, for regulators to show capital measures, and run stress tests, with marketimplied capital values alongside those based on book values.

When I made the supplementary stress test suggestion to the Bank of England, part of the response was that low price-to-book ratios can be explained by expected future profitability being weak for reasons other than poor asset quality. But a bank's obligations to depositors and bondholders are met, or not, by future cash flows. Their weakness is a problem, or could be, whatever the cause of the low ratios. And if a systemic crisis hits, which is our principal concern, the ability to sell assets that might have been good quality pre-crisis might well evaporate. Anyway, if regulators have explanations to offer for low price-tobook ratios, those could be published, for public scrutiny, alongside market-based capital ratios.

Sarin and Summers ${ }^{7}$ consider whether persistently low interest rates can explain low priceto-book ratios. Higher interest rates could boost banks' margins on unremunerated deposits and a steeper yield curve could enhance the profitability of maturity transformation more generally. Indeed "the boost to net interest income as sterling interest

\footnotetext{
${ }^{7}$ Sarin and Summers (n 3).
} 
rates rise" is a feature of the Bank of England 2018 stress tests. ${ }^{8}$ On the other hand higher interest rates reduce the value of long-term assets held by banks. So the effect is mixed in theory, and Sarin and Summers find "very little support" in the empirical evidence for the proposition that low interest rates explain subdued market views of bank profitability.

Moreover, where price-to-book ratios are substantially below one, there is a limit to how much can be explained by weak short-term profitability. The Bank of England used a cost of bank equity as high as $13 \%$, together with a five-year period of depressed profits, to reconcile an average price-to-book ratio of between 0.7 and 0.8 in 2016 . With mainstream assumptions on the risk-free rate and the equity premium, a $13 \%$ cost of equity implies a bank beta of about 2. (More on betas later.)

The profit projections in Bank of England stress tests have not in fact been weak. The chart below is from the 2017 exercise. $^{9}$

Chart A1.2 Projections for aggregate profits before tax

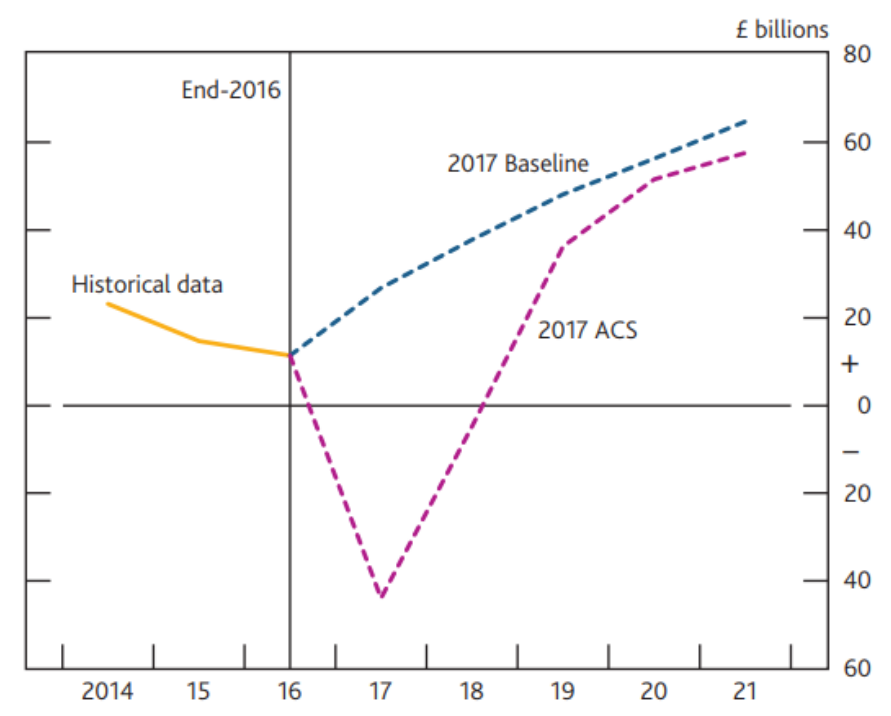

The blue dotted line shows the baseline - i.e. the central projected profit path in the absence of the stress. This rises by tens of billions of pounds, relative to the historical data shown in yellow, which declined, contrary to projections of strong profit growth in prior stress tests. The stressed path, the purple dotted line, is sharply below the baseline in the first couple of years of stress, but then rebounds close to the buoyant baseline projection,

\footnotetext{
${ }^{8}$ Bank of England, Financial Stability Report, November 2018, page 4.

${ }^{9}$ The corresponding chart was not published in 2018 but I imagine it is similar. The baseline in the corresponding chart for 2016, adjusted for misconduct costs, was used in a dividend discount model in the reconciliation exercise described in the Governor's letter ( $n$ 4). For a critique of recent Bank of England stress tests, see Kevin Dowd, 'No stress III: Flaws in the Bank of England's stress testing programme' (2017) Adam Smith Institute.
} 
to a level well above the recent path. This is a prime reason why banks appear quite resilient to the stress.

Accounting measures themselves evolve. Thus International Financial Reporting Standard 9 was introduced at the start of 2018. IFRS 9 requires earlier recognition of losses. Unlike its predecessor (IAS 39), which required banks to book credit losses only once there was evidence of impairment, IFRS 9 sensibly requires banks to provide for expected credit losses. This changes the time profile of losses in stress, recognising them in a more timely way. But EU banks have been given "transitional relief", so that a portion of expected losses may be added back to CET1 capital until 2023. This is hardly an advert for the rigour of CET1. The Bank of England showed its 2018 stress test results with and without transitional relief but, concerned to avoid "an unwarranted de facto increase in capital requirements as a result of the stress test", it lowered the hurdle rates in the pure IFRS 9 case.

For a bank that is a sound going concern in all circumstances - a question that cannot be begged - the move to IFRS 9 changes only the time profile of losses, not their aggregate amount. But travelling along different paths can have different implications. One concerns so-called Additional Tier 1 capital, which in Europe may include contingent convertible bonds (co-cos). Their triggers are accounting measures of capital, which is another illustration of how part of the commercial and contractual structure, in addition to the regulatory edifice, is dependent on those measures.

\section{PRO-CYCLICALITY ISSUES}

An important objection to the use of market measures in stress tests concerns procyclicality - that capital as valued by the market would tend to be high in stock market booms and low in slumps, while counter-cyclical policy should be contractionary in booms and expansionary in slumps. A related concern ${ }^{10}$ is about the volatility of stress test results, but one wonders whether that might be saying more about the banks being tested than the methodology of the test. Anyway the proposal is not to ditch current stress tests, but simply to supplement them with market-based tests when price-to-book ratios are low.

Following Morris and Shin ${ }^{11}$, an illiquidity component of credit risk might in some circumstances be reflected in market prices. Illiquidity risk is the risk that a solvent bank, which would not otherwise have failed, fails because of a run by creditors and/or because of balance sheet weakening due to fire sales of assets. If illiquidity risk is elevated, market values might underestimate bank solvency - i.e. the expected value of assets if held to maturity, less obligations to creditors. If market measures reflecting illiquidity risk

\footnotetext{
${ }^{10}$ See Randal Quarles, 'A new chapter in stress testing', speech at the Brookings Institution, 9 November 2018.

${ }^{11}$ Hyun Shin and Stephen Morris, 'Illiquidity component of credit risk' (2016) 57 International Economic Review 1135.
} 
mechanically drove policy on capital requirements, undesirable pro-cyclical dynamics could indeed unfold. ${ }^{12}$

But there is no suggestion that capital requirements should be market-driven, and anyway one might ask why illiquidity would risk be elevated unless there were at least some market doubts about solvency. That would itself seem to be important market information with a bearing on the question of whether accounting values can be relied on for regulatory and other purposes.

Moreover, considerations of pro-cyclicality do not weigh against the use of market measures to calibrate capital when, as now for much of the world, bank's price-to-book ratios are below one despite economies and stock markets being in a prolonged upswing. If they are below one in an upswing, what will things be like in a downswing?

This question is examined in section 4 of Sarin and Summers. ${ }^{13}$ The Fed stress tests involve a large drop in the stock market. Since US bank betas range from about 1.2 to 1.8 , the effect on the stock market valuations of banks is magnified further. The upshot is that some of the biggest banks have their tangible common equity capital buffers, as measured by the market, wiped out in the event of such a large fall in the stock market. If bank betas increased in severe downturns, the effect would be greater still. Market-implied capital losses are estimated to be more than double those in the Fed stress tests.

To use the earlier terminology, this analysis is an example of the ex post method of using projected market values as the stress test evolves, not just to set their starting positions. It asks whether the change in bank capital levels looks market-consistent. The authors make the caveat that this is "an admittedly naïve exercise", but it raises important questions. If market-implied values of bank capital would be substantially below the stressed values based on accounting measures, what explains the difference? Whether or not there are convincing explanations, this is a question that deserves an answer.

Of course there are now policy instruments to address pro-cyclicality directly, notably the counter-cyclical capital buffer. But little use has been made of it. It is set at zero in the United States, and shown in the ESRB chart below for May 2019, it is zero in most of Europe too, despite us not appearing to be in a cyclical slump. Since the availability of the countercyclical capital buffer tool has been given as a reason ${ }^{14}$ for lowering estimates of optimal

\footnotetext{
12 In similar vein, Guillaume Plantin and Jean Tirole, 'Marking to market versus talking to market' (2018) 108 American Economic Review 2246, show in a theoretical model how, beyond a certain point, marking to market can adversely affect liquidity in secondary markets for assets.

${ }^{13}$ Sarin and Summers (n 3).

${ }^{14}$ At least by the Bank of England: see John Vickers, 'The systemic risk buffer for UK banks: a response to the Bank of England's consultation paper' (2016) 2 Journal of Financial Regulation 264.
} 
baseline capital requirements, its net effect on the safety of the banking system has become unclear.

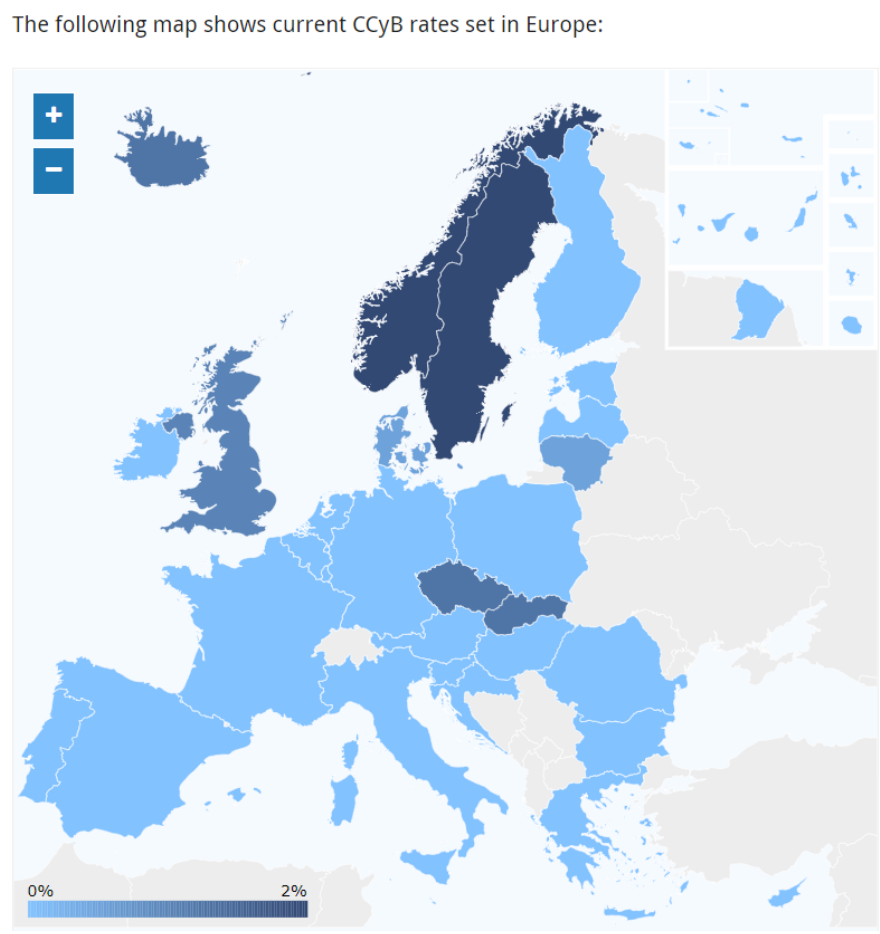

\section{COMMUNICATION ISSUES}

A further objection to running alternative supplementary stress tests is, to quote Governor Carney, "the risk of confusing the Bank's communication around its stress tests. If we publish two sets of results that give different messages, people might struggle to understand what we are trying to say about the resilience of the banking system". ${ }^{15}$ Maybe so, but clarity of message should not have priority over stress test rigour. Where different bases of calculation, both of them reasonable, deliver different answers about the resilience of the banking system, that is important for people to know. And it is best that they hear it, with explanation, from the regulators themselves.

I can however see the awkwardness, for a regulator who has been emphasising the resilience of the system, of publishing market-based measures that may present a different picture. But that is what accountability requires, and it goes some way towards ameliorating the incentive problem of regulators being perceived as marking their own exam papers when conducting stress tests of a system that they have already declared to be safe and sound. And to the extent that it exerted a discipline on such declarations that might be no bad thing.

\footnotetext{
${ }^{15}$ At $n 4$.
} 


\section{STRESS TESTS AND DEFINED BENEFIT PENSION SCHEMES}

Stress tests apply not only to banks. For example, there are Life Insurance Stress Tests, and the Bank of England's Prudential Regulation Authority ${ }^{16}$ is currently consulting on the design of its stress test for insurers. ${ }^{17}$ The scenario proposed for the stress involves a drop in riskfree (nominal and real) interest rates of 100 basis points at all maturities, and a widening of corporate bond spreads of $150 \mathrm{bps}$ for bonds rated AAA pre-stress, $170 \mathrm{bps}$ for AA bonds, and more for lower rated bonds.

The main focus of the stress test is on the third party annuity liabilities that the insurers have taken on, but their own staff pension schemes are also involved, and for them the stress works as follows:

"For the valuation of pension scheme liabilities, firms should assume that the discount rate would change by the level of any change in the risk-free rate plus $50 \%$ of the change in spread on AA rated corporate bonds. Under the proposed stress the risk-free rate decreases by $100 \mathrm{bps}$ and $50 \%$ of the spread on AA rated corporate bonds is an increase of $85 \mathrm{bps}$. Therefore, both elements combined result in a $15 \mathrm{bps}$ fall at all tenors to the discount rate".

For an insurer that had not hedged the risk-free interest rate risk in its scheme, a 100bp drop in the discount rate could have a substantial effect on the size of liabilities, and hence on the firm's capital. But the assumed jump in credit spreads comes to the rescue, or $85 \%$ of it anyway, so undoes most of the liability stress.

In economic terms this is very puzzling. Why have credit spreads jumped in the postulated scenario? Largely, if not wholly, because corporate credit risk has risen because of the stress. Indeed for non-sovereign bonds there is a 2 notch downgrade in option 1 of the stress test. If the insurer is holding corporate bonds, the risk that those assets will not pay out in full is therefore assumed to have increased. The value of those bonds in its asset portfolio will fall. But the obligation to pay pensions is not weakened by the rise in credit spreads, so it is hard to see why the insurer's pension liabilities should be reduced - at all on account of it. On the face of it, this curious regulatory accounting treatment of pensions also dilutes the stress test. It may also have implications for the measurement of insurers' capital levels.

\footnotetext{
${ }^{16}$ Prudential Regulation Authority, 'Life insurance stress test 2019: Scenario specification, guidelines and instructions', April 2019.

${ }^{17}$ I am grateful to Dean Buckner and Kevin Dowd for pointing me to this. Their Eumaeus Project blog has further discussion of the PRA insurance stress tests, and of the Solvency II method of "matching adjustment", whereby annuity liabilities may be discounted at a rate above the risk-free rate.
} 
This example of pensions accounting illustrates a wider point, which is that we economists should try harder to understand the accounting methods upon which so much of the financial system and its regulation depends. Whether or not they make economic sense is a really important question, especially bearing in mind that "capital" - the value of assets less liabilities - is an accounting construct and not like a pot of money. To the extent, if any, that regulatory accounting methods do not make economic sense, perhaps they make some other kind of sense that deserves priority. But that question should be out in the open.

\section{CONCLUSION}

To sum up, the stability of the financial system depends on the capital of banks and other financial institutions. Unlike the amount of money in a pot, capital cannot be counted. Its measurement depends on regulatory accounting methods, which, as events a decade ago showed dramatically, do not always reflect economic realities in a timely fashion. Market valuations of capital are imperfect too. But they deserve systematic attention, especially when they appear to be in tension with accounting measures of capital. This can and should be done, officially as well as academically, in various ways. In particular, for major banks with price-to-book ratios less than one, stress tests based on market values should be run and published by regulators alongside existing stress test results.

What if they give different answers? That big question is for another day, but the response must depend on the diagnosis for the difference. I can imagine some diagnoses where one would at least question the dividend policy of banks that fail stress tests based on market values. 